Eurostudia

\title{
Silence during the National Anthem
}

Why Sports are Still Something Else in East Germany

\section{Robert Ide}

Volume 5, numéro 2, décembre 2009

Le retour de l'histoire ? Répercussions européennes et internationales de la réunification allemande

URI : https://id.erudit.org/iderudit/1001459ar

DOI : https://doi.org/10.7202/1001459ar

Aller au sommaire du numéro

\section{Éditeur(s)}

Le Centre canadien d'études allemandes et européennes

ISSN

1718-8946 (numérique)

Découvrir la revue

Citer cet article

Ide, R. (2009). Silence during the National Anthem: Why Sports are Still Something Else in East Germany. Eurostudia, 5(2).

https://doi.org/10.7202/1001459ar

Tous droits réservés ( Le Centre canadien d'études allemandes et européennes, 2011
Ce document est protégé par la loi sur le droit d'auteur. L'utilisation des services d'Érudit (y compris la reproduction) est assujettie à sa politique d'utilisation que vous pouvez consulter en ligne.

https://apropos.erudit.org/fr/usagers/politique-dutilisation/ 


\section{SILENCE DURING THE NATIONAL ANTHEM Why Sports are Still Something Else in East Germany?}

Robert Ide

Sports Editor, Tagesspiegel, Berlin

Dear ladies and gentlemen,

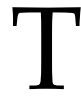

hank you very much for coming and thank you also, for inviting me to come all the way to Montreal. This has been one of my furthest journeys abroad. Just one other took me even further - to a new country which used to be my homeland and then disappeared: from the GDR to Germany. I would like to tell you about this journey and to my transition from an East German Sports fan to a German Sports spectator.

I first saw the wall when I was a small child. It ran behind my parents' allotment garden in the north of East Berlin and we could see the newly-built housing blocks of West Berlin rising above it - strangely enough though, they didn't appear in my school atlas. It only showed a grey spot where West Berlin was supposed to be. Nonetheless, people in those houses over there would sometimes open a window or watch us gardening or barbecuing. For us those people didn't exist, they weren't allowed to exist.

The family garden was a niche where we sought refuge from the State and could dream of the West - free and undisturbed. Only, the peculiar thing was that our family retreat was right next to the most rigorous of all the borders which the State had erected for us. Still, we never heard a gunshot in our garden ... just the watchdogs barking. My family permanently expected the unexpected. Every day we saw soldiers in uniform, shotguns at the ready, staring coldly. They sat in converted and camouflage-painted Trabant cars patrolling the border. Once they brought my sister home (in their camouflage painted Trabi). She had dug up an 
alarm wire with her toy spade. That put an end to her playing at the Wall, although the sand there was finer than at the seaside. It took quite some years before I understood. They didn't want plants to grow at a wall where six hundred to a thousand people had lost their lives.

As a school boy I photographed the wall. When I went to collect the photos, the shop had developed all of them except for the pictures of the border. Someone had picked them out; but who? Already at this young age I realised that I should forget about the Wall and that I mustn't talk about it either. In Pankow, planes crossed the sky above our heads on their way to the West Berlin airport, Tegel. Strictly speaking, these planes were nonexistent for us. But we always gazed longingly after them.

I wanted to become a sports reporter after my parents had taken pains to talk me out of my other career aspiration: to be Erich Honecker. I longed to travel around the world and report on the truth. That this was impossible for a political journalist of the GDR, I had already realized when I got into trouble with my school magazine. I had called it "Brennpunkt". My school director reacted by asking me: "How could you call it Brennpunkt?" Don't you know there is a TV show in West German TV called "Brennpunkt"? "Of course not", I lied. "You know, we never watch West German TV at home." The director couldn't say anything. I had learned to speak double-tongued already as a child. Everyone in the GDR knew how to.

But of course, I didn't want it to be that way in my professional life as a journalist. So, at the time I thought: Better choose the sports' world. When the GDR national team lost 1:2, no one could claim it had won 2:1. Admittedly, organised doping wasn't yet on the cards.

When the GDR fell over itself, the sport sector broke down too. Nobody was interested in Katarina Witt anymore, who had already had a boyfriend in Canada now everyone wanted to go to Canada themselves. Sport heroes were exchanged like cars, new East German ones traded for used ones from the West. 1990 reunified Germany won the World Cup with Lothar Matthäus, well respected back then because he only played soccer and wasn't the protagonist of his public relationship crisis. I attended the games of Hertha BSC in West Berlin's Olympic stadium. We wanted to belong. And in the beginning the entrance was free for East Germans.

On the rare occasion when a child of the GDR became an all-German hero - as did 14-year-old swimmer Franziska van Almsick - one was especially happy, because 
at last someone had really shown it to the West German establishment. And one didn't listen when she claimed she had always had a pan-German perspective. You couldn't escape your past, not even by swimming, every child could see that.

Professional cyclist Jan Ullrich was also a star of the reunified sport sector before he caught up in the quicksand of doping. The new perspective on fraud remains a legacy of reunification. The process of accounting for forced doping in the GDR, especially of children, was a painful experience. Victims that are still suffering from health problems were compensated only minimally - so that sport mirrors society in that respect too.

Sport has remained something special for East Germans. Adopting new money and new laws was one thing, finding new loves was another. Especially since the old ones are still there. Today, twenty years after the fall of the Berlin Wall, I still say "here", when referring to East Germany. That has nothing to do with nostalgia; more so with the perceived loss of home.

I didn't sing the new national anthem until the World Cup 2006. It was only when Germany was host to soccer and the cultures of the world and a new ease settled in, as light as a flying ball, that I was able to sing along. In Leipzig, the only East German venue, people went to their basements to get their old flags from the Monday demonstrations: Black, Red and Gold with a hole from the cut-out GDR emblem. It was a special sign of arriving in a country that was one's own.

Reunification in the sport sector was successful, at least emotionally. The conditions of play however still differ widely - as they do in society. East German soccer clubs are non-existent in the German Bundesliga (Germany's Premier League). Illustrious clubs like Dynamo Dresden or the First FC Magdeburg still suffer from long-term damage of post-reunification confusion. The only club with money is an artificial product of capitalism in Leipzig, owned by a producer of beverages that wants to "give wings" to the club. Otherwise, despite many new arenas and pits, the East German turf is not exactly in full bloom.

Pan-German clubs only exist in the reunification workshop Berlin. Right next to the city's old borders spectators from both East and West go to watch sports. The "Eisbären", the Polar Bears, no longer enchant the masses in a shack in Hohenschönhausen but lure them into the big new arena between former East German district Friedrichshain and former West German district Kreuzberg. The old supporters still shout "Dynamo" and "Ost-Berlin", the new ones cheer by clapping along to the beat with their cardboard fans. 
The reunified sport sector has been reflecting more on itself. This is not necessarily a bad thing. The Olympic bids of Berlin and Leipzig, imagined as catalysts for East German sports, failed, but Munich is not doing so well either at the moment. The concept of sport healing society's wounds may thus still be regarded somewhat skeptically.

Today I'm Sports Editor at the "Tagesspiegel", a newspaper from former West Berlin, which has been attracting more and more readers from the East. I became a sports writer (after all) but write about doping, the pressure to perform and sport as a mirror of society. And I tell my own stories for a new understanding of each other.

I still recall how I spent the 100 German West Mark, which was handed out to every East German on his first visit to the West - on a double cassette tape recorder. One Mark was left over. I spent it on a kiwi. When we paid, my Mum asked the Turkish greengrocer how to cook the kiwi. His infectious laughter still echoes in my ears:" Peel, don't boil!" And he gave us another kiwi for free so that we could practice. Ask any East German - they will all have a similar tale to tell embarrassing but heart-warming.

I saw the wall already when I was a child. Its fall taught me that life doesn't have to be predetermined; dreams don't have to be for nothing. Hope can pay off - this is the most important lesson that I learnt from the collapse of the Wall. Ans, sometimes, love can change.

My sister, who once dug up an alarm wire next to the Wall, has now become an energy electrician - she is still fascinated by wires. She runs her own company in former West Berlin and lives close to me in the former East of the city, our old home.

On my way to Montreal the plane started from Berlin Tegel. I flew first over the entire city and then all the way to you, to the other side of the world, a world that doesn't have frontiers for me anymore.

Thank you very much. 